\title{
Climate change impacts and responses in the Philippines coastal sector
}

\author{
Rosa T. Perez ${ }^{1, *}$, Leoncio A. Amadore ${ }^{1}$, Renato B. Feir ${ }^{2}$ \\ ${ }^{1}$ Philippine Atmospheric, G eophysical and Astronomical Services Administration (PAGASA), Agham Road, Diliman, \\ Quezon City 1104, Philippines \\ ${ }^{2}$ Coast and G eodetic Survey Department (C GSD) of the N ational M apping and Resource Information Authority (N AM RIA), \\ Department of Environment and Natural Resources (DE N R), 421 Barraca St., San Nicolas, M anila, Philippines
}

\begin{abstract}
The Manila Bay coastal area in The Philippines was evaluated for the possible consequences of accelerated sea level rise in the context of climate change and to assess adaptive responses to such threats. The coastal area is an important region in terms of commercial, industrial, agricultural, and aquacultural activities of The Philippines. Results show that areas along the coast if inundated by a $1 \mathrm{~m}$ sea level rise would include coastal barangays from 19 municipalities of M etro Manila, Bulacan, and Cavite and would cover an area of 5555 ha. Proposed response strategies consist of protecting the coast by building sea walls; institutional actions such as formulation of setback policies and construction regulations; and adaptive planning in the context of an integrated coastal zone management to address the short- and long-term problems, with the involvement of communities in the area. Information, education, and communication are essential along with the technical and scientific efforts to achieve a well-balanced adaptation plan.
\end{abstract}

KEY WORDS: Accelerated sea level rise · Vulnerability · Sustainability · A daptation · Integrated coastal zone management plan

\section{INTRODUCTION}

Accelerated sea level rise (ASLR) is one of the most certain outcomes of global warming. With a coastline of $34000 \mathrm{~km}$, The Philippines takes a serious view of the potential effects and possible responses to ASLR. The physical effects of sea level rise include inundation (submergence) of low-lying wetland and dryland areas, erosion, salt water intrusion, increased risk of flooding, and storm damage. In turn, these physical changes may cause substantial socio-economic losses of coastal structures, both natural and man-made, and dislocation of the population and change of livelihood. The same physical changes may bring about certain ecological consequences such as redistribution of wetlands, destruction of coral reefs, reduction in biological diversity and loss of wildlife, and changes in biophysi-

*E-mail: laapagasa@pdx.rpnet.com cal properties of the coastal zones. To avoid these unwanted changes, it may be necessary to invoke a range of possible responses such as construction of seawalls and dikes, upgrading of coastal infrastructure in consideration of high water levels, relocation of coastal populations, mangrove regeneration, or other options.

The detailed impact assessment of Manila Bay coastal area was undertaken by the Philippine Country Study to Address Climate Change through one of its study elements: Vulnerability Assessments and Evaluation of Adaptations on Coastal Resources Due to Accelerated Sea Level Rise (ASLR). The objectives of this study element are as follows: (1) study the possible effects of ASLR on the coastal ecosystem of Manila Bay; (2) examine the possible effects of ASLR on socioeconomic structures and activities in the coastal areas of Manila Bay; (3) formulate response strategies by identifying potential costs and benefits; (4) identify needed actions to develop a long-term coastal zone management plan; (5) develop the capability to apply 
the methodology to other areas in The Philippines; and (6) brief policy/decision makers on the vulnerability of The Philippines to ASLR and the urgent need to mitigate or adapt to climate change.

\section{VULNERABILITY ANALYSIS AND ADAPTATION ASSESSMENT}

The methodology adopted for this study is essentially that of the 7 steps or 'Common Methodology' of the Coastal Zone Management Sub-group (CZMS) of the Intergovernmental Panel on Climate Change (IPCC 1990). However, this method was followed quite loosely because of some data and information gaps. The 7 steps are: (1) delineating the study area and specification of ASLR scenarios; (2) inventorying the study area characteristics; (3) identifying relevant development factors; (4) assessing physical changes and natural system responses; (5) formulating response strategies and assessments of their costs and effects; (6) assessing the vulnerability profile and interpretation of results; and (7) identifying needs and a plan of action.

2.1. Delineation of the study area and specification of ASLR scenarios. For the present study, the Manila Bay area (Fig. 1) is considered for evaluation of the possible consequences of ASLR and to draw adaptive responses to such threats. The provinces of Bataan, Pampanga, Bulacan, Cavite, and some of the towns and cities of M etro Manila along the eastern side bound the highly enclosed bay. Manila Bay is located in the western midsection of

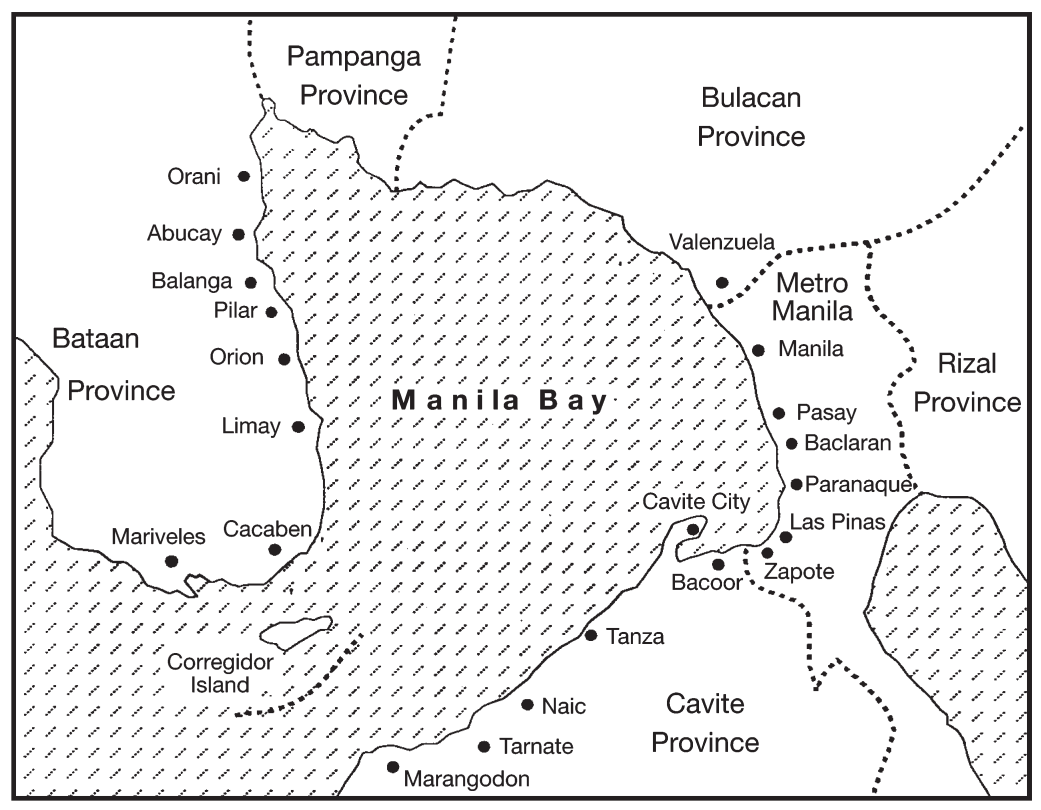

Fig. 1. The study area. The provinces of Bataan, Pampanga, Bulacan, Cavite, and some of the towns and cities of M etro M anila along the eastern side bound the highly enclosed bay
Luzon. It lies between $120^{\circ} 35^{\prime}$ and $121^{\circ} 00^{\prime} \mathrm{E}$ and $14^{\circ} 15^{\prime}$ and $14^{\circ} 50^{\prime} \mathrm{N}$ and has a coastal perimeter of $800 \mathrm{~km}$. The Manila Bay coastal area plays an important role in the country's economy in terms of industry and commerce, agriculture, aquaculture, and tourism. It is one of the country's oldest traditional fishing grounds. Even before the arrival of the Spaniards, Manila Bay had been the hub of economic activity in trade and transportation. Today, Manila is the seat of the national government while the rest of the provinces are some of the constituents of the national capital region and nearby political regions. The bay is considered to be the second most productive fishing ground in The Philippines next to the Visayas seas. Fishponds and fish and shellfish pens proliferate along Bulacan, Bataan, Cavite, and the northern M etro $M$ anila coastlines. The North and South Harbors in the city of Manila provide support to the international and domestic shipping industry. The bay is adjacent to the most densely populated, urbanized, and industrialized area in the country. This has led to some of its present problems. The city of $\mathrm{M}$ anila and its surroundings have the necessary infrastructure that attracts most of the country's economic pursuits. Coupled with the perceived lack of opportunities in the rural areas, people began their mass migration to the city - an exodus the ecosystem is hard-pressed to support. With very little concern for or ignorance of environmental requirements, wastes have been indiscriminately dumped into the air and water, eventually finding their way into M anila Bay, destroying fragile food chains. In addition, deforestation in the uplands causes topsoil erosion, which renders these areas unsuitable for productive agriculture; increased siltation damages valuable ecosystems such as corals, seagrasses and seaweeds.

The study set the boundary conditions of an accelerated sea level rise of $0.3,1.0$, and $2.0 \mathrm{~m}$ by the year 2100 . The first 2 values are the low and high estimates of IPCC, while a $2.0 \mathrm{~m}$ rise represents a worst-case scenario.

2.2. Inventory of the study area characteristics. 2.2.1. Physical environment: Tidal gauge data from a station at Manila South Harbor $\left(14^{\circ} 35^{\prime} \mathrm{N}, 120^{\circ} 58^{\prime} \mathrm{E}\right)$ show an increasing trend in the mean sea level (Fig. 2). The bay experiences a tidal regime ranging from $-0.475 \mathrm{~m}$ to a high level of $0.529 \mathrm{~m}$ (based on CGSD records). The coastline of Manila Bay is $190 \mathrm{~km}$ long, and the coasts are generally gently sloping. These are covered by a soft clayey deposit of Alluvium age. The groundwater level averages from 50 to $150 \mathrm{~m}$ below sea level. 


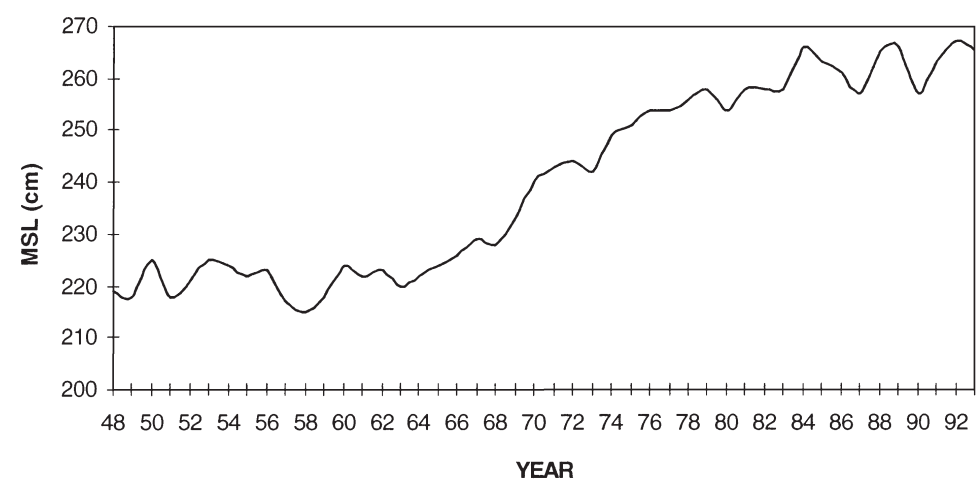

Fig. 2. Annual mean sea level observed at Manila Tide Gauge Station, 1948-1992

Two pronounced seasons are experienced in the bay area: dry from December to May, and wet from $J$ une to November. The maximum rain period is from $J$ une to September and the area is generally exposed to the southwest monsoon. Forty-five years of records (1948 to 1992) from the Climatological and Agrometeorological Branch of PAGASA shows that 5.64\% of the total tropical cyclones crossing the country passed over the area, a frequency of about 5 cyclones in every $3 \mathrm{yr}$. Without reference to climate changes, the bay coastal area has already been subjected to several hazards such as flooding and storm surges during tropical cyclones and liquefaction and tsunamis during earthquakes. A good proportion of the surge occurrences raised water levels up to $2 \mathrm{~m}$. Shoreline changes due to reclamation for housing, ports, coastal roads, buildings, and other urbanized developments have increased the potential threat of inundation.

2.2.2. Resource profile of Manila Bay: The living ecosystems in the bay include rivers, mangroves, seagrasses/seaweeds, coral reefs, and swamplands. These ecosystems play vital roles in the fishery resources and, hence, the income of those who are most dependent on nearshore fishing in the bay. In all provinces surrounding Manila Bay, the coastal ecosystems are currently highly stressed by unsound or unsustainable practices.

A pproximately 131 rivers traverse all of the coastal municipalities and drain into the bay. The majority of these rivers are suffering heavily from improper dumping of wastes, especially those that are located in the urbanized coastal areas surrounding Manila Bay (DENR-EMB 1996).

There are 2 types of mangrove forests within the bay (BFAR 1994): the natural secondary growth and the mangrove reforestations. These are mostly found in Bulacan, Cavite, and Bataan. Mangrove associates, known locally as the nipa, also abound in Bulacan. For the areas around the bay, the mangroves are endan- gered. Some areas are already deforested, such as in Tanza, Cavite, where the area is now cleared, with few trees and a lot of stumps remaining. According to local sources, the mangroves in the area were harvested for firewood and other domestic uses. The majority of mangrove areas have likewise been converted to fishponds, especially in the Bulacan-Pampanga areas. This occurred in the late 1970s and early 1980s, when aquaculture was largely encouraged by the government. Conversion is usually the last recourse towards the destruction of this valuable ecosystem. On the other hand, seagrasses and seaweed are fast-vanishing species in the area. Table 1 summarizes the area covered by these resources.

In the case of Tarnate, Cavite, the coral reefs are located in the areas owned by private groups (such as Puerto Azul), such that the exploitation for fishing is controlled by the resort management. Also, the local communities (Barangay Patungan and Carabao Islands in $\mathrm{M}$ aragondon, where reefs are found) are relatively aware of the importance of these reefs. Key local sources have confirmed that trawlers who tried to operate in these areas were advised to operate somewhere else or face sanctions (legal or otherwise).

There are approximately 55000 ha of fishponds in the coastal municipalities of Manila Bay. The types of fishponds and area covered are presented in Table 2.

2.2.3. Economic profile: The coastal household population based on the total number of barangays (264) in the study area is about 800000 (National Statistics Office 1990). The sectoral composition of the population is shown in Table 3.

Lightly built houses in coastal communities are located in the areas most proximate to the shore; in some cases, they are built over the water itself. Shanties and houses on stilts are evident particularly in the municipalities of Bacoor, Kawit, Cavite City, and Rosario in Cavite; Navotas (Barangay Tanza) in Metro Manila; Orion in Bataan; and some areas in Bulacan

Table 1. Areas in Manila Bay covered with mangrove, swampland, seagrasses, and seaweeds per province (BFAR 1994)

\begin{tabular}{|lrcccc|}
\hline $\begin{array}{l}\text { Province/ } \\
\text { region }\end{array}$ & $\begin{array}{c}\text { Mangrove } \\
\text { (ha) }\end{array}$ & $\begin{array}{c}\text { Swampland } \\
\text { (ha) }\end{array}$ & Seagrass & Seaweed \\
\hline Bulacan & 259.00 & - & None & Yes \\
Pampanga & 748.00 & 3762.34 & None & None \\
Cavite & 37.94 & 311.41 & Yes & Yes \\
Bataan & 220.00 & - & Yes & Yes \\
Metro Manila & 10.50 & - & None & None \\
Total & 1275.44 & & & \\
\hline
\end{tabular}


Table 2. Types of fishponds and the areas (ha) that they cover in M anila Bay (data extracted from the socio-economic profiles of the different municipalities, 1995)

\begin{tabular}{|c|c|c|c|c|c|}
\hline Province/region & Freshwater & Government leased & $\begin{array}{l}\text { ackish wat } \\
\text { Private }\end{array}$ & Mixed & Total \\
\hline Bataan & 21.36 & 571.18 & 3126.35 & - & 3718.89 \\
\hline Bulacan & 231.85 & 9646.06 & 2679.00 & 7975.91 & 20532.82 \\
\hline Cavite & 5.00 & 6.40 & 1130.23 & & 1141.63 \\
\hline Pampanga & 6569.56 & - & - & 22193.69 & 28763.25 \\
\hline Metro Manila & - & - & 633.50 & - & 633.50 \\
\hline Total & 6827.77 & 10223.64 & 7569.08 & 30169.60 & 54790.09 \\
\hline
\end{tabular}

and Pampanga (usually along riverbanks). The settlement areas near the shore are usually congested and have small floor areas. Many of the houses have no sanitary facilities for the disposal of waste, which is indiscriminately dumped into the waters of Manila Bay.

The working age bracket for individuals is defined to be from 15 to $60 \mathrm{yr}$ old. This age group constitutes about $61 \%$ of the population. However, less than $50 \%$ of the employable age bracket are gainfully employed, the percentage per area of which is shown in Fig. 3 (ICEE 1997).

Fishing in the bay is a critically important occupation or source of income. About $40 \%$ have fishery-based occupations, which include municipal fishermen, commercial fishing operators, mussel farm/fishpond operators, fish worker crews, fishpond workers, mussel farm workers, fish traders, and fish processors. The other $60 \%$ are in non-fishery-based occupations such as farming, service establishments, and informal businesses (convenience stores and vending), among others. Minimal income is derived from the various livelihood activities, resulting in the low economic status of the coastal households. Low income is also attributed to other factors such as low fish yield, marketing problems, limited livelihood and employment opportunities, and limited skills outside of fishing.

2.2.4. Industry profile: According to the records of the Department of Trade and Industry (DTI), 26802 establishments are registered in the 30 coastal municipalities around the Manila Bay area. As part of the

Table 3. Sectoral composition of Manila Bay's population (ICEE 1997)

\begin{tabular}{|lc|}
\hline Age bracket & Percentage \\
\hline Children (15 yr and below) & 37 \\
Young adult (16-35 yr old) & 38 \\
Middle aged (36-59 yr) & 21 \\
Elderly (60 yr and above) & 4 \\
\hline
\end{tabular}

major industries existing within the coastal provinces, CALABARZON and the Export Processing Zone Authority (EPZA) can be considered as the major establishments that have successfully generated employment opportunities for thousands of residents located near these 2 industrial centers through increased manufacturing activities. The CALABARZON project involves the provinces of Cavite, Laguna, Batangas, and Quezon, or the CALABARZON region. The project is characterized by a set of anchor projects in the categories of port development, roads and highways, industrial support projects, urban development, agriculture, rural development, and environmental management.

In general, the pressing problems of the coastal communities include environmental degradation, unequal distribution of resources and opportunities, illegal fishing, and apathy of the people. Low environmental awareness and concern are a large contributory factor to the existing resource problems of the bay. This is shown in the continued involvement of the fisherfolk in destructive and illegal fishing methods and in the poor health sanitation of coastal households in general. Organized fisherfolk and other coastal residents are said to have made an effort to address the environ-

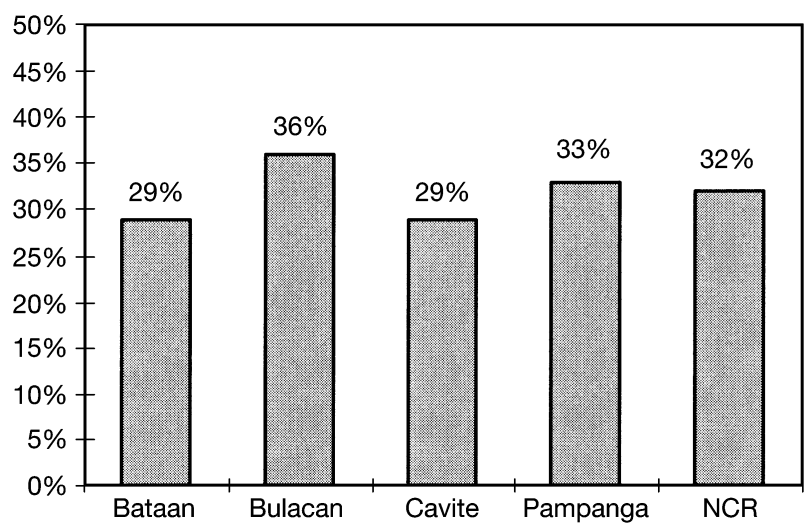

Fig. 3. Percentage of population in each region of M anila Bay in the working bracket that is actually employed 
mental problems of the bay. These efforts, though, tended to be limited and had no widespread impact on the rest of the communities around the bay. This may be partly attributed to the perception that the government, despite its inability to implement coastal and fishery laws, has the primary responsibility for managing the bay's resources. Directly or indirectly, factors contributing to this low awareness and concern about the environment include poor education, limited or minimal flow of information, poor health and sanitation awareness, and ineffective enforcement of laws.

2.3. Vulnerability analysis. Topographic and bathymetric maps are important sources of data for the vulnerability assessment of the impacts of ASLR in the coastal areas. However, for most developing nations, high-resolution maps are difficult to obtain. M ost of the coastal charts that are available have 10 to $100 \mathrm{~m}$ contour intervals, which are virtually useless when analyzing the prescribed scenarios. Supplementing existing data by means of airborne photogrammetry is costly, both in terms of funds available and time allocated for the vulnerability analysis and assessment of adaptations. Satellite imagery can also be very expensive or not easily obtained. A technique developed by Leatherman et al. (1995) called Aerial Videotapeassisted Vulnerability Analysis (AVVA) has been adopted by the present country study. In effect, this technique covers Steps 3 to 6 of the IPCC common methodology. AVVA is a reconnaissance-level assessment of the implications of land use in response to sea level rise. It involves unrectified oblique aerial videorecording of the coastal area taken from a height of 50 to $500 \mathrm{~m}$, limited ground truth information, archival research, and analysis of the data in conjunction with simple land loss and response models.

2.3.1. Base maps: The finest resolution maps used in this study have a scale of 1:10000 with $4.0 \mathrm{~m}$ contour lines and spot heights. Similarly scaled land use maps were also obtained from CGSD for references.

2.3.2. Aerial survey: A UH-IH model helicopter was flown over the area of the Manila Bay coastline. The first low-level pass was taken at $75 \mathrm{~m}$ altitude from Bataan to Cavite and back. The $300 \mathrm{~m}$ level survey had to be suspended due to heavy air traffic in the area. The survey included still pictures and $8 \mathrm{~mm}$ video coverage.

2.3.3. Ground truth measurements: The main objective of the field survey was to delineate the specified boundary conditions for the ASLR scenarios: $0.3,1.0$ and $2.0 \mathrm{~m}$ contours, along the coast, and the major changes that had occurred there since the last updating of the topographic maps of the area. The main work consisted of establishing geodetic controls (points of known geographic positions and elevations) along the coast spaced approximately at $2.5 \mathrm{~km}$. Supplemen- tary controls were established in low elevation areas extending significantly inland.

Ground profiling was also done where spot heights were obtained. The spacing of spot heights depended largely on the nature of the terrain (i.e. closely spaced heights for steep slope). The heights and positions of these spot heights were then plotted on survey forms to obtain the 0.3 and 1.0 m contours. High-resolution $2 \mathrm{~m}$ contour lines were drawn on existing maps by interpolating between the $4 \mathrm{~m}$ contour lines.

2.4. Identification of needs and actions. Selection of the appropriate response will depend on site-specific conditions (as reflected in the results of the vulnerability analysis), costs, land use, and coastal infrastructure. Some issues and concerns for consideration in responding to ASLR are as follows:

(1) The costs of the responses must be assessed.

(2) Assuming that the coastal resources cannot be protected, the main political factor to be considered is the necessity to relocate people and infrastructures likely to be affected by ASLR. The big question is: What policies or laws are required to do so?

(3) Adoption of policies and laws restricting habitation and investment in vulnerable areas may be necessary.

(4) Public education about the coastal environment is needed to sensitize the government and the people about the issues involved-that is, the danger and possible solutions.

(5) Any rise in sea level will likely increase the level of flooding both in magnitude and duration. Major development projects such as flood protection embankments or levees have to address these problems.

(6) Basic research is needed aimed at a better understanding of coastal processes, rational use of coastal resources such as mangrove forests and coral reefs, and artificial coastal protection.

(7) Dislocation of people and changes in livelihood must be addressed. At the turn of the century, it will not be uncommon to hear about 'environmental refugees'. Responsible agencies must be ready to intervene.

(8) Long-term development within the context of an integrated coastal zone management plan must be put in place by all agencies concerned. Some of the coastal management issues that address sea level rise are (i) management of shoreline flood plain hazards for the protection of life and property, including evacuation planning and protective works, (ii) prevention of salt water intrusion through judicious use (conservation) of fresh water, (iii) preservation of public access and regulation of coastal recreation areas, (iv) protection of people and economics at risk, and conservation of wetland, estuaries, and nearshore habitats, and (v) planning the sustainable development of vulnerable natural resources like ground water, sand, and corals. 


\section{RESULTS AND DISCUSSION}

\subsection{A erial survey}

The aerial survey confirmed the presence of several types of coastal environments in the M anila Bay area. These are the brushland/industrial environment of southern Bataan, the agro-aquacultural environment of the Bataan-Pampanga coasts, the aquacultural and urban environment of Bulacan and northern Metro $M$ anila, the highly urbanized environment of Metro $M$ anila, the tourism and agro-aquacultural environment of Cavite, and the natural environment of southern Cavite (Perez et al. 1996).

Initial observations also revealed erosion at the Bataan coasts and other shoreline changes due to reclamation for various land usages, especially in the $M$ anila-Cavite areas. The presence of squatter areas (areas occupied by homeless citizens who do not have their own legitimate dwellings) along the river deltas of Bataan, Bulacan, and M etro M anila emphasized the increased vulnerability of the area. The river outlets to the bay from Pampanga and Bulacan are noticeably heavily silted with lahar deposits. There has been extensive land reclamation for fishponds along the coasts of southern Bulacan, although previously it was known that the Department of Agriculture disapproved of this practice as it had serious detrimental environmental effects. A check with the Bureau of Fisheries and Aquaculture Research revealed that leases or permits for ponding along Manila Bay had been canceled since 1967 by a Presidential Decree on Fishpond Leasing/Developments.

Only 2 areas within the bay were identified as forested. These are the extreme ends of Manila Bay in Bataan (M ariveles) and in Cavite (Maragondon). The $M$ etro Manila shoreline has been greatly restructured by the high level of urbanization. As a result of the extensive economic developments that have been carried out, the area is now almost devoid of natural vegetation. This is also the only place in the bay coastline where physical protection structures are noticeable. The agricultural lands (ricefields) of Cavite are mostly near the shore, while those of Bataan and Bulacan are landward of the fishponds.

Most of the coasts in the northern portion of the bay are characterized by a muddy substrate, while toward the south the shores have a sandy substrate. Shoreline changes due to reclamation for urbanized developments are quite significant over Parañaque (residential subdivisions), Pasay (Cultural Center of the Philippines Complex), Las Piñas-Cavite (coastal road). Erosion is mostly evident in the beach areas of Cavite, most probably due to sand quarrying, and in some abandoned fishponds of Bulacan.
Data from the Public Estates Development shows that a total area of $17.74 \mathrm{~km}^{2}$ has been developed along the coast of Manila Bay over the last $40 \mathrm{yr}$. This figure is further broken down into $8.16 \mathrm{~km}^{2}$ for fishpond development and $9.28 \mathrm{~km}^{2}$ for urbanized developments such as settlement areas, road network expansion, port facilities development, and institutional/ recreational complexes.

\subsection{Vulnerability to accelerated sea level rise}

From the graph in Fig. 2, it is quite noticeable that the mean sea level in Manila Bay abruptly rose in the late 1960s. Although Manila is known to be below sea level and sinking, the rising sea level observations are not believed to be the result of land subsidence since the instruments are calibrated periodically and the reference site tested for stability (Carandang 1989).

Shallowing of the nearshore areas is generally due to the natural processes of soil erosion and siltation. Several reasons can be cited, such as the unsound resource-use practices in the upland (for example, slash-and-burn farming) and indiscriminate disposal of wastes and garbage in the coastal areas that has hastened and intensified these natural processes.

Infrastructure development, whether in the interior or in the coastal areas, generally causes adverse effects to the coastal zone in the long term. Land reclamation projects like the one being carried out along the Pasay and Parañaque areas, for example, had caused a lot of siltation in the nearshore areas of these 2 towns.

Baseline information on the natural ecosystem reveals the sad state of corals and other fish habitats, such as seagrasses, in the bay. This decline is directly attributed to water pollution and increased siltation of the bay's waters. Similarly, mangrove forests in the coastal areas are definitely vanishing due to human intervention. In their present condition, if ASLR does occur, these weakened ecosystems may not keep pace with the warmer temperature and reduced light (because of increased turbidity). Corals are sensitive to water temperature (warmer water causes a condition known as 'bleaching' of the corals). For their growth, corals also need light. The growth of mangroves is usually affected by the salinity of water. Mangroves, which are found mostly in estuaries, may not be able to survive the increased salinity when the sea level rises. Several anthropogenic causes for the decline of mangroves, corals and seagrasses can be mentioned. They include the following: (1) Mangrove forests have been converted into fishponds, saltbeds, rice paddies and even for residential, commercial, and industrial purposes. (2) Mangroves have been overexploited for timber use, firewood, and tanbarks. (3) Philippine 
mangroves are affected by pollution due to mining and dumping of mine tailings and solid wastes. (4) Siltation has been an important factor in the destruction of coral reefs. The Zambales area that was affected by lahar and ashfall is an example. Another cause of deterioration of corals is water turbidity and water temperature. (5) A mong the major causes of the decrease in seagrass beds is siltation due to agricultural cultivation and mining. Natural causes like storm surges, tsunamis, and volcanic activity affect the productivity and lifetime of sea grasses.

The decline of wetlands/freshwater swamps may be traced to the lack of a coherent balanced policy on the proper use and management of such lands and to the fact that these areas have been declared as built-up areas. There are issues involving public easements and buffer strips, illegal construction of permanent structures, and squatting on easement areas. Non-compliance of the public to Presidential Directive 953 (planting trees along the riverbanks) can be viewed as due to laxity in the implementation of this directive (or lack of a monitoring mechanism).

There are also indications that agricultural productivity drinking water quality will be affected by saltwater intrusion into coastal soils and freshwater aquifers. This, in turn, is seen to seriously affect human health and livelihood.

Results of the vulnerability analysis showed that most areas along the coast of M anila Bay - specifically, Cavite City, Noveleta, Kawit, Imus and Bacoor in the province of Cavite, some parts of Las Pinas and Parañaque, Malabon, Navotas in Metro Manila, and parts of Bulacan such as Hagonoy and Malolos-could succumb to a $1 \mathrm{~m}$ sea level rise by 2100 . Even inland areas would be affected, especially near riverbanks, when sea level rise reaches a height of $2 \mathrm{~m}$. However, the most densely populated areas (which are also currently economically depressed) of Malabon and Navotas may survive a gradual increase in sea level, but not in conjunction with the more intense storm surges that periodically hit Manila Bay. The surgeprone areas of Limay and Orani, Bataan, are vulnerable in the same way.

Maps of the Manila Bay area showing vulnerability to the different ASLR scenarios are presented in Fig. 4. Even without climate change, the areas prone to inundation due to the $0.3 \mathrm{~m}$ sea level rise have been reported to suffer flooding during high tides. Table 4 summarizes the tentative areas prone to inundation in the different sea level rise scenarios. Further verification is still needed through photometric or actual field survey.

Based on computer models developed by the Commission on Population (PopCom), the University of the Philippines Population Institute (UPPI), and the
Future Group, the population of The Philippines is estimated to reach 143 million by the year 2025 (DOH/USAID 1993). Further, keeping the growth rate from 1990 to 1995 constant, the population of The Philippines is estimated to increase to more than twice the 1995 level by the year 2025. With this development, the number of people to be affected by a $1 \mathrm{~m}$ ASLR (Table 5) by the year 2025 is estimated to reach about 2.3 million, though this projection may be an overestimate because the base data is for all municipalities.

\subsection{Commitment to sea level rise}

One strategy to adapt to future sea level rise is through long-term planning in the context of integrated coastal zone management (ICZM) practices. ICZM is a 'process of governance consisting of the legal and institutional framework necessary to ensure that the development and management of the coastal zones are integrated with environment and socioeconomic goals in a community-participatory process' (Post \& Landin 1996). Some of the areas in The Philippines - such as Lingayen Gulf, Davao Gulf, Cebu, and Batangas Bay - are already implementing ICZM, particularly practices that constitute sound environmental management and wise use of resources and, to a lesser degree, address coastal disaster preparedness and emergency response. Still lacking in these plans are appropriate responses to present-day climatic variability (such as EI Niño events) and natural hazards, and, eventually, to climate changes and the impacts to the coastal resources.

Table 4. Endangered areas in different projected sea level rise scenarios for the year 2100

\begin{tabular}{|cc|}
\hline Sea level rise scenario $(\mathrm{m})$ & Area to be inundated (ha) \\
\hline 0.3 & 2090 \\
1.0 & 5555 \\
2.0 & 8905 \\
\hline
\end{tabular}

Table 5. Projection of population that will be affected by a $1 \mathrm{~m}$ sea level rise by the year 2025. 1990 and 1995 data supplied by National Statistics Office

\begin{tabular}{|c|c|c|c|}
\hline Place & 1990 & 1995 & 2025 \\
\hline $\begin{array}{l}\text { The Philippines } \\
\text { Cavite } \\
\text { Metro Manila } \\
\text { Bulacan }\end{array}$ & $\begin{array}{r}62049000 \\
230506 \\
429600 \\
130000\end{array}$ & $\begin{array}{r}68614000 \\
257706 \\
510794 \\
140790\end{array}$ & $\begin{array}{r}143096245 \\
658762 \\
1443228 \\
227166\end{array}$ \\
\hline \multicolumn{4}{|c|}{ Total: 2329156} \\
\hline
\end{tabular}




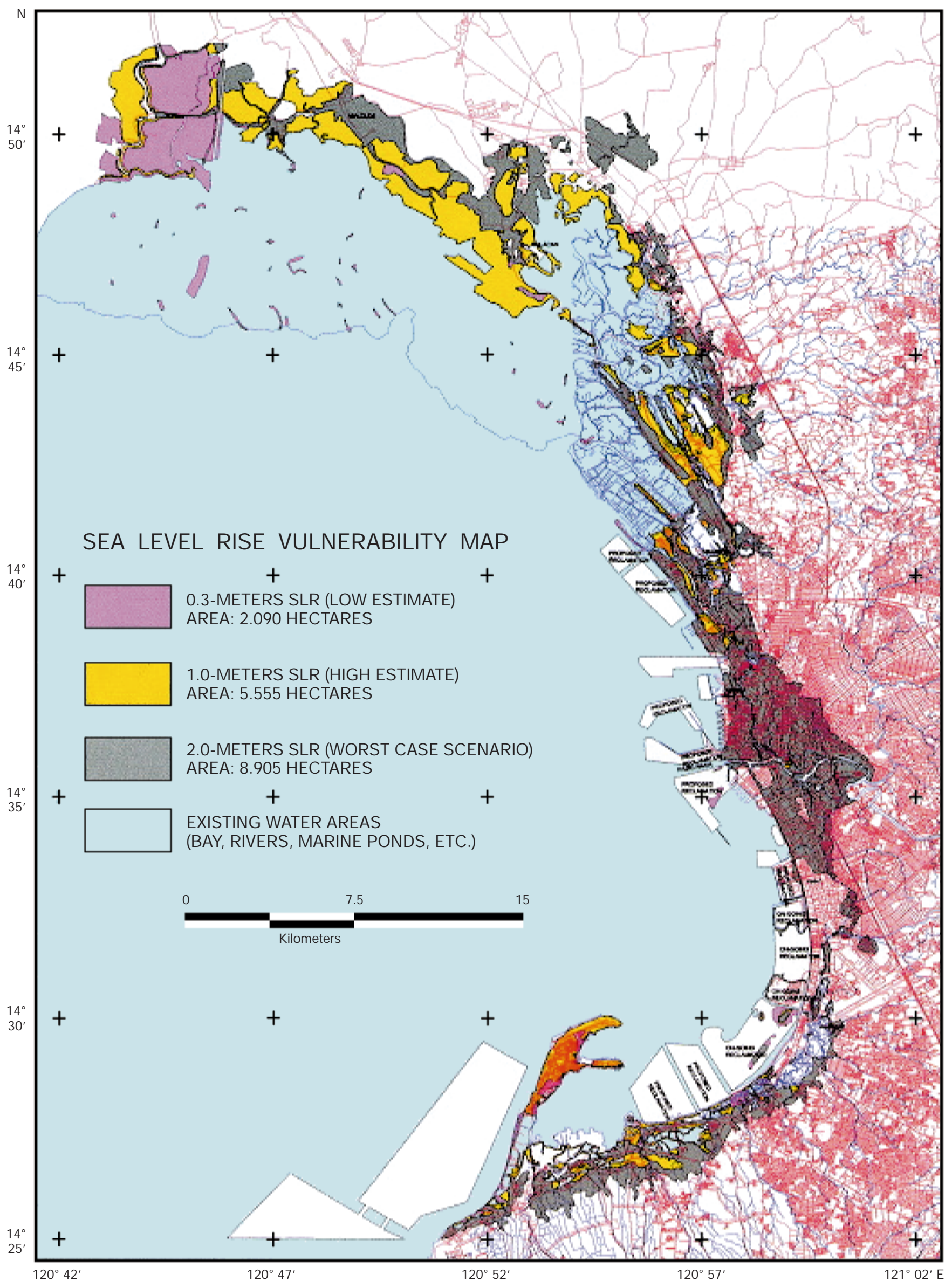


Fig. 4. Areas found in M anila Bay to be vulnerable under the different sea level rise scenarios. The red areas are prone to inundation due to the $0.3 \mathrm{~m}$ sea level rise; the yellow color signifies the areas likely to be affected by a $1.0 \mathrm{~m}$ sea level rise; while the gray-colored areas are most likely to be inundated by a $2 \mathrm{~m}$ sea level rise

ICZM is basically a cooperative effort on the part of all coastal zone stakeholders, resulting in a 'win-win' outcome. It is a dynamic process in which a continuing strategy is developed and implemented for the allocation of environmental, socio-cultural, and institutional resources to achieve the conservation and sustainable multiple use of the coastal zone. In judging the need to include climate change factors in the analysis of ICZM, an assessment is required of the relative importance of the various agents with respect to both the short- and long-term impacts. The decision will revolve around 2 concerns, vulnerability and sustainability. For example, the lifetimes of structures and implementation times of measures are within time scales during which significant increases in sea level rise may occur. In this regard, short-term development and solution may become unsustainable in view of the long-term impacts of sea level rise. However, ICZM has to begin as early as possible to increase preparedness to deal with the potentially far-reaching impacts of climate change upon the coastal areas.

\subsection{G overnment's capability}

Since the 1970s, the Philippine Government has formulated programs and projects on coastal resource management. It received funding supports from multilateral funding institutions to develop concepts and management schemes related to fisheries and mangroves. At present, the government is implementing the Fisheries Sector Program (FSP), which seeks to put into place the coastal resource management schemes in 12 priority bays.

$M$ angrove reforestation is one of the components of FSP. Reforestation is being undertaken through contracts with private companies. But this scheme was modified when DENR started implementing the Coastal Environmental Program (CEP) in 1993. The CEP seeks to develop coastal communities as resource and environmental managers; hence, the task of mangrove reforestation was transferred to these communities.

Under the CEP, 12 pilot areas, one in each geographical region, were selected to demonstrate sites for implementation of community-based coastal resource management. In each pilot area, a massive information campaign is conducted to inform the people about the program. A community organizing or devel- opment officer then organizes the people. The community organization takes 1 to $3 \mathrm{yr}$. During this period, the community leaders are trained to manage cooperatives and people's organizations, and the community is assisted in developing a management plan for its coastal area. The program has 5 components-namely (1) conservation and management of habitats, including the establishment of coastal/marine protected areas; (2) protection of endangered species; (3) monitoring and control of coastal pollution; (4) inventory/ assessment of coastal resources; and (5) applied research and special projects.

The Local Government Code (LGC) of 1991 (RA 7160) empowered local government units (LGUs) to plan and implement development programs or projects within their areas of jurisdiction. Under the LGC, coastal resource management is the primary responsibility of LGUs (Pimentel 1993). The LGC gives the LGUs the autonomy to pursue their own development as far as the bay's resources are concerned. This also affords them with an opportunity to effectively initiate these opportunities without waiting for the national government to make the first move. However, the fact that different political units encompass the Manila Bay coastal areas makes coordinated effort a relatively difficult problem, because each political unit has its own developmental agenda.

There are no clear-cut policies on the use and management of wetlands and marshes, or even on the preservation of mangroves and coral reefs and other precious coastal ecosystem.

In other instances where policies, laws, or regulations have been set up, some institutional problems still pose barriers to effective implementation. Among these are institutional weakness (or lack of political will) at different levels of government, especially in the LGUs to which the function of managing municipal waters was devolved. Enforcing agencies lack the resources to effectively enforce existing laws, rules, and regulations.

\section{RECOMMENDATIONS}

\subsection{Proposed policy intervention}

In general, it is proposed that an assessment of current practices on crisis management should be done, as climate change may exacerbate or increase the fre- 
quency of extreme events such as droughts, floods, or storms. Greater awareness of climatic variability and change, which are not well understood by the public or decision-makers, should be promoted. Increasing sensitivity to climate issues will facilitate the public acceptance and subsequent adoption of measures to prepare for climate variability and climate change. Such measures include the following:

(1) Formulating guidelines and legislation for the implementation of integrated coastal zone management for all coastal zones in The Philippines. Land use planning in coastal zones will help reduce vulnerability to a rise in sea level.

(2) Institutionalizing development and protection of mangrove resources. This can be made possible through the formulation of additional policies and regulations or by amending existing policies and regulations to allow effective and sustainable mangrove management characterized by a massive reforestation of degraded mangrove systems through a communitybased approach.

(3) Requiring that LGUs reserve foreshore areas that are critical for recreation/ tourism purposes and other public uses and that they be excluded from disposition.

(4) Including wetlands, swamps, and marshes in the National Integrated and Protected Areas (NIPAS) within a category of wildlife sanctuary or unique ecosystem.

(5) Developing a multi-hazard mitigation and protection plan for natural coastal hazards, with priority on the maximum reduction in threat to life, structures, and economic production.

(6) Formulating and strictly implementating mining laws, and reforesting denuded watersheds to reduce river and coastal erosion.

(7) Requiring geological, hydro-meteorological, and structural engineering evaluation as part of the environmental impact assessment prior to coastal development.

(8) Limiting government subsidies or tax incentives to develop land sensitive to sea level rise, such as barrier islands, coastal wetlands, estuarine shorelines, and critical wildlife habitats.

(9) Promoting awareness about climate change impacts on coastal zone systems such as erosion, sea level rise, flooding risks and storm/earthquake standard building codes could be a cost-effective means of reducing future expenditures.

\subsection{Institutional vehicles for implementation and role of stakeholders}

In The Philippines, much of the coastal zones and the adjacent ocean and most of the resources are usually under public ownership. Hence the programs to manage such areas and resources are operated by the government for the benefit of the people. In cases where properties are privately owned, the management is left to the owners. In an ICZM program, important roles will exist for specialized agencies at the national and local government levels, for research institutions, for users and owners of the coastal zone and its resources, and for the general public.

Coastal stakeholders are individuals or groups of individuals involved in the activities that take place in the coastal zone. They could also be those who place a high value on the aesthetic, touristic, and recreational value of the coastal zone. The economic survival of these stakeholders depends largely on the health of the coastal zone. Hence, the different stakeholders must be jointly involved in the development and implementation of the ICZM process. This group usually provides the drive and momentum to sustain an ICZM process and help generate the political will to elicit action among the government policy-makers.

Community groups are the direct beneficiaries of any long-term management plans in the coastal areas. They consist of the fisherfolk and their families, coastal zone workers, community leaders, or just ordinary members of the community. These people can be encouraged to become involved in the day-to-day ICZM tasks. Examples are monitoring of ambient water quality of streams; carrying out clean-up activities on coastal lands such as seashores; monitoring discharges from various coastal zone activities; helping to develop watershed management activities; and adopting community-based mangrove reforestation and sustainable fishing techniques. They also can serve as active watchers of what is taking place in local waters and report to authorities illegal fishing and coral reef poaching. Although individual efforts are solicited and appreciated, it is the accomplishments of an organized group over the long term that are most effective.

One sure way to lessen vulnerability to the impacts of climate changes is to increase resiliency through sustainability. The government can urge those who stand to gain most to get involved with projects. Small fishing communities will support and maintain sustainable use programs, such as approved fishing methods or preservation and nourishment of coral reefs, if they derive tangible benefits from their efforts (White 1989). The incentives for ensuring a marine ecosystem include sustainable, continued supply of fish, improved conditions of coral reefs, increasing number of tourists who come to scuba and dive, and the pride derived from sharing the management techniques and successes with neighboring communities, among others. 


\section{CONCLUSION}

M any may view climate change and sea level rise as too overwhelming and too remote. Perhaps this is because the issue does not fit within the political time frame of $6 \mathrm{yr}$, which is typical for elected officials. Nevertheless, activities must begin in anticipation of the resulting impacts. Considering that many coastal resources in the Manila Bay area are already in severely stressed conditions and declining, vulnerability is high and could further lead to unsustainability.

The vulnerability analysis showed that the Manila Bay area is vulnerable to sea level rise from both physical and socio-economic standpoints. M ost areas along the coast will succumb to a $1 \mathrm{~m}$ sea level rise, specifically about 19 municipalities of Metro Manila, Bulacan, and Cavite. Areas that could be inundated by $0.3 \mathrm{~m}$ sea level rise al ready experience flooding during high tides (for example, Navotas, $M$ alabon, and Dagatdagatan areas). Densely populated areas along the coast, especially the areas inhabited by squatters in Navotas and Malabon, may survive ASLR but will be very vulnerable to the severe storm surges that are likely to increase in frequency and severity. Coral reefs and wetlands are al ready heavily stressed and may not keep pace with the changes in sea level. Mangroves may not survive changes in sediments and salinity. Saltwater intrusion will affect agricultural productivity and water quality. Considering present (1995) costs, coastal protection will be an expensive solution. For example, a concrete sea wall $3 \mathrm{~m}$ high and $1 \mathrm{~m}$ thick with an underwater base that is $1.5 \mathrm{~m}$ high and $3 \mathrm{~m}$ thick will cost US $\$ 0.6$ million $\mathrm{km}^{-1}$.

To be able to carry out all of these strategies, an extensive information and education campaign to inform policy-makers and the general public of the issues and concerns of ASLR must be carried out.

There is an urgent need to review and integrate all measures, policies, and management plans to avoid costly duplication and increase the coordination between and among all the coastal stakeholders. The involvement of the communities or the so-called 'grass roots' will serve as the strongest cohesive factor that will ensure the success of any sustainable use program of the government. The LGUs should be equipped with the proper technical know-how, together with the power to execute all rules and regulations pertaining to the utilization, development, and rehabilitation of resources.

Acknowledgements. This study was supported by grants from the Country Studies Program for Climate Change of the Government of the United States of America and the Philippine Government under the auspices of PAGASA. Sincere thanks go to the staff of the Natural Disaster Reduction Branch and the Climatology and Agrometeorology Branch of PAGASA and the Coast and Geodetic Survey Department of NAMRIA/DENR.

\section{LITERATURE CITED}

Bureau of Fisheries and Aquaculture Research (BFAR) (1994) Annual report: 1993. Department of Agriculture, Quezon City

Carandang E (1989) A study on the variation of sea level, Manila Bay. Technical Report, CGSD, NAM RIA, Manila

Department of Environment and Natural ResourcesEnvironmental Management Bureau (DENR-EMB) (1996) Philippine environmental quality report: 1990-1995. DENR, Quezon City

Department of Health (DOH)/USAID (1993) A look in the Philippine population and socio-economic realities. DOH, Manila

Institute for Climate, Environment and Energy (ICEE) (1997) A report on the socio-economic study on Manila bay area. Inter-Agency Committee on Climate Change (Philippines)

IPCC (1990) Sea level rise: climate change: the IPCC scientific assessment. Cambridge University Press, Cambridge

Leatherman S, Nicholls RJ, Dennis KC (1995) Aerial videotape-assisted vulnerability analysis: a cost effective approach to assess sea level rise impacts. J Coastal Res Spec Issue 14:15-25

National Statistics Office (NSO) (1990) Philippine statistical yearbook. NSO, Manila

Perez RT, Feir R, Carandang E, Gonzalez E (1996) Potential impacts of accelerated sea level rise on the coastal resources of Manila Bay water. Air Soil Pollut J 92:137-147

Pimentel AQ (1993) The local government code of 1991: the key to national development. Cacho Publishing House, Inc, Metro Manila

Post J C, Landin CG (1996) Guidelines for ICZM. World Bank M onograph Series No. 9, Washington, DC

White AT (1989) Two community-based marine reserves: lessons for coastal zone management. In: Chua TE, Pauly $D$ (eds) Coastal zone management in Southeast Asia, policies, management strategies and case studies. ICLARM, Manila 